\title{
Study on the Dot Gain and Tone Reproduction of Tissue Paper
}

\author{
Ying $\mathrm{Li}^{1}$, Haishan $\mathrm{Li}^{2, a}$ \\ ${ }^{1}$ Faculty of Mechanical and Electrical Engineering, Kunming University of Science and Technology, \\ Kunming, 650500, China \\ ${ }^{2}$ Kunming Richfun Printing Co., Ltd, Kunming, 650217, China \\ ${ }^{a}$ Corresponding author: haishanying@126.com
}

Keywords: Tone reproduction; Dot gain; Dot percentage; Tissue paper

\begin{abstract}
The rate, quality and economics of printing process are tightly linked to the characteristics of printing technology and materials used. Paper printability is variable property which is according with press conditions and printing characters. A kind of tissue paper used in industrial applications for Puer tea packaging was studied. Tissue paper for Puer tea packaging should have good air permeability because Puer tea needs ferment. Ink receptivity is one of the most important properties of tissue paper in terms of the print quality. The ink receptivity is too strong and ink will not set onto the paper, which make poor color and tone reproduction. Tissue paper was printed with offset fast-drying inks to examine the conditions of tone reproduction, color reproduction and dot gain which determined the printing quality. The immediate objective of this study was to investigate dot gain and tone reproduction of tissue paper.
\end{abstract}

\section{Introduction}

Paper printability has two kinds of properties which are printing operation applicability and printing quality applicability [1, 2]. Printing operation applicability means that paper can make printing operation smoothly and successfully. Printing quality applicability means that paper properties are detrimental to printing quality. Paper printability includes paper physical-chemical properties which include ink receptivity of paper, air permeability, surface roughness, water absorption, tensile strength, bursting strength, and surface strength etc [3-5]. Tissue paper for Puer tea packaging belongs to uncoated paper and fibers arrange out of order and sparsely. When inks from plate meet substrates, a colored organic pigment in inks will penetrate into tissue paper rapidly. The formation of ink film with the desired optical density on paper substrates is consequentially dependent on the ink receptivity by paper, which is determined by structure and optical properties of paper surface [6]. The development of print gloss is related to the rate at which the ink film hardens or sets, which in turn may be related to the pore structure of the paper surface [7-9]. Tissue paper can not perform the role of substrate smoothly. The main aim of our study was to obtain the surface properties of tissue paper and printability and to find which kind of press product tissue paper adapted to.

\section{Experimental}

Materials. Four kinds of tissue paper were used in our study which had different grammage. Proofing inks were offset printing fast-drying inks which were cyan, magenta, yellow, black. Overprint vanish was also offset printing fast-drying ink.

Methods. Tissue paper samples were air-conditioned before measurements, which were carried out under the same conditions. Tissue paper samples were printed in the cylinder proof press under the same conditions. Cylinder proof press was indirect printing. The blanket performed the transfer of four-color offset inks onto the tissue paper samples. Proof inks were offset printing fast-drying inks which were cyan, magenta, yellow, black. There were obviously different characteristics which can be observed directly by eyes between top side and underside of tissue paper. Overprint vanish was transferred onto top side and underside of tissue paper by cylinder proof press. Four-color printing was performed with four kinds of tissue paper samples which were top side, underside, top side vanished and underside vanished of tissue paper. Each tissue paper sample included cyan, 
magenta, yellow, black four-color controller strips. Each color controller strip included five kinds of printing areas in which dot area coverage were $20 \%, 40 \%, 60 \%, 80 \%$ and $100 \%$. The optical density of printed tissue paper samples was measured after 24h applying reflection densitometer X-Rite 530(USA).

\section{Results and Discussion}

Tone Reproduction. Fig.1 shows the tone reproduction curves measured using yellow, magenta, cyan and black offset ink onto top side of tissue paper substrate. Optical density of ink films increased gradually with the dot percentage increasing. The differences of curves $\mathrm{r}$ are obvious. Mean value of density of black ink is highest at the same dot percentage and the Mean value of density of yellow ink is the lowest one because black ink has strong coverage capability and yellow ink has good transparence.

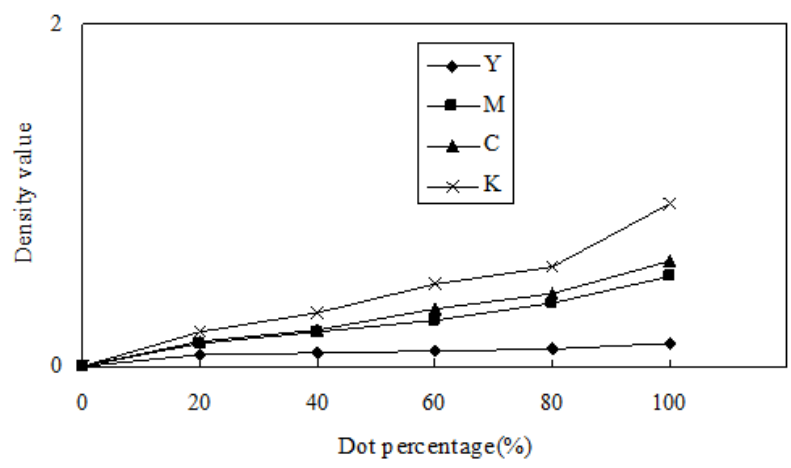

Fig.1. Tone reproduction curves measured using yellow, magenta, cyan and black offset ink on to top side of tissue paper substrate.

Dot gain. Color printing quality is determined by tone and color reproduction which are achieved through dot transferring onto the paper substrates. The size, change and quality of dot and thickness of ink film are the basic factors which determine the printing quality. The optical density of ink film and dot gain value are the significant factors. Dot gain value is given as:

$$
Z_{D}=F_{D}-F_{F}
$$

Where $Z_{D}$ is the dot gain value; $F_{D}$ is the dot percentage of printing material; $F_{F}$ is the dot percentage of plate. $\mathrm{F}_{\mathrm{D}}$ can be described by Marray-Davies Equation:

$$
F_{D}=\frac{1-10^{-D_{R}}}{1-10^{-D_{V}}}
$$

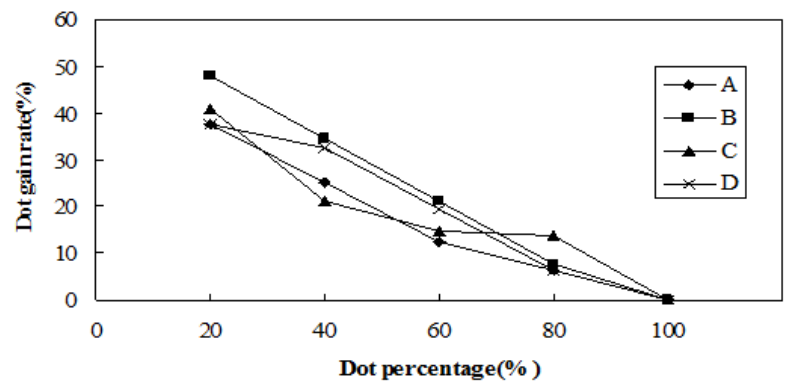

Fig.2.The relation between dot percentage and dot gain rate when tissue papers were printed with yellow ink: A top side unvarnished; B underside unvarnished; C topside vanished; D underside vanished.

Where $\mathrm{D}_{R}$ is the reflection density of measurement; $\mathrm{D}_{\mathrm{V}}$ is the solid density of printing material. The results indicated dot gain percentage reduced gradually with the dot percentage increasing (fig.2, 3, 4, 5) dot gain got the highest value at the point of the lowest dot percentage. Tissue paper properties have a important role on the dot gain when the ink film is very thin. The results (table 1) showed tissue paper had high pore rate. A lot of dots could not set onto the surface of the tissue paper, which resulted in dots missing under the condition of low dot percentage. These factors leaded to serious dot gain. Dot gain value of yellow ink was higher than the value of magenta ink 
and cyan ink at any point of dot percentage (fig.2). The properties of tissue paper have a big influence on yellow ink transferring and setting because yellow ink has good transparence. Dot gain phenomenon is more apparent on underside of tissue paper than top side, which indicates topside of tissue has better printability than underside. It can be seen that dot gain of yellow ink was most serious so tone reproduction of yellow was worst (fig.6).

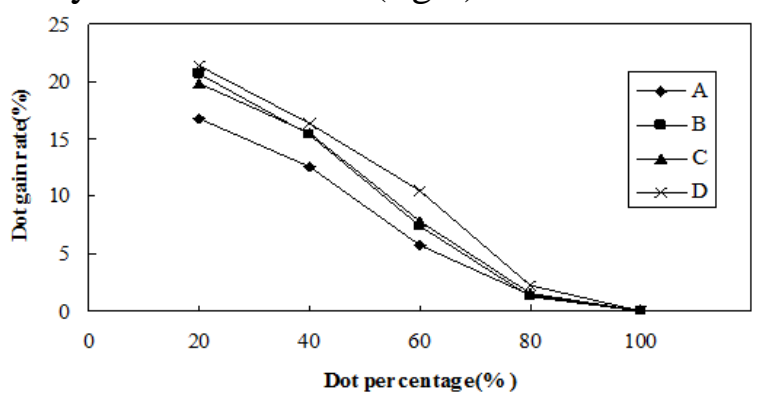

Fig.3.The relation between dot percentage and dot gain rate when tissue papers were printed with magenta ink: A top side unvarnished; B underside unvarnished; $C$ topside vanished; $D$ underside vanished.

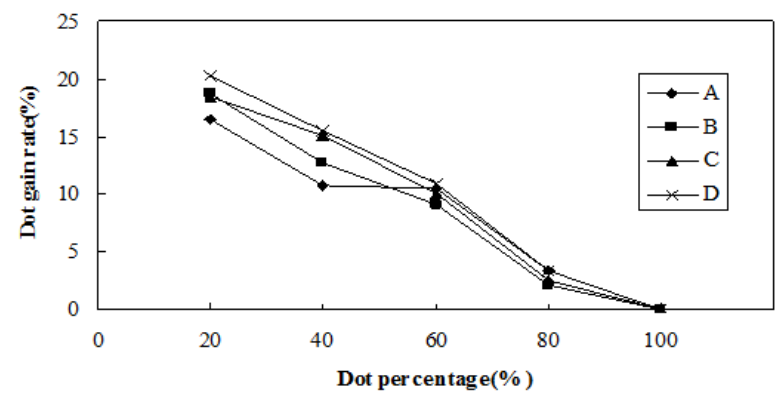

Fig.4.The relation between dot percentage and dot gain rate when tissue papers were printed with cyan ink: A top side unvarnished; B underside unvarnished; C topside vanished; D underside vanished.

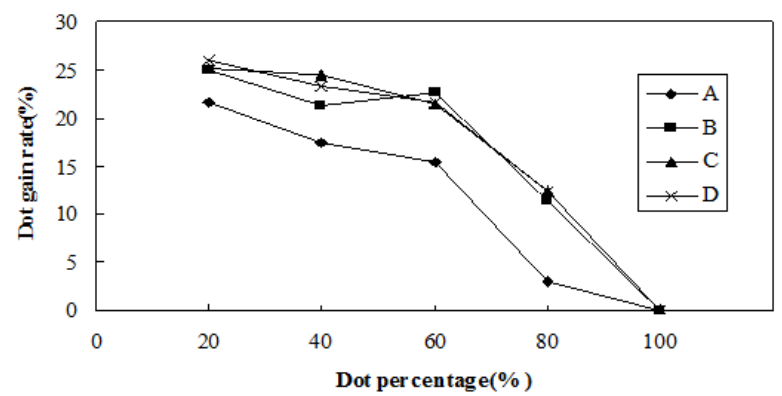

Fig.5.The relation between dot percentage and dot gain rate when tissue papers were printed with black ink: A topside unvarnished; B underside unvarnished; C topside vanished; D underside vanished.

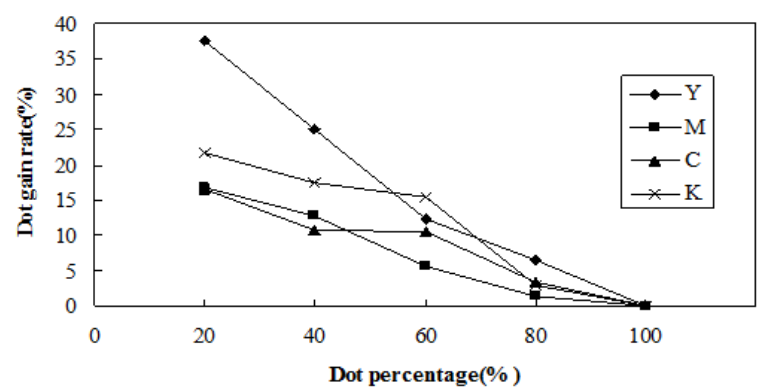

Fig.6.The relation between dot percentage and dot gain rate when top side unvarnished tissue papers were printed with yellow, magenta, cyan and black offset ink.

\section{Conclusions}

The work has shown the tone reproduction and dot gain of tissue paper. Tone reproduction of top 
side is better than underside. The formation of the ink film onto the paper substrates by printing process is substantially influenced by paper-ink interactions. Tissue paper fibers arrange sparsely and out of order, which lead to high pore rate on the surface of tissue paper. Ink penetrates easily into the internal of tissue paper and can not set on the surface of tissue paper to form a certain ink film thickness. Dot gain rate reduces gradually from light tone to shadow tone. Dot gain phenomenon is more apparent than the common packaging materials we often use and serious dot gain make gray balance not to be controlled, which can not guarantee the printing quality with the substrate of tissue paper. The study shows that the tissue paper may not be used for press products which demand high precision, abundance of colors and tone and adapt to the press products which only include line, color block and test areas.

\section{Acknowledgements}

The authors express their gratitude to the Yunnan Province Science and Technology Department (Project KKSY 2012/01059 and KKSY 2012/01051) for financial support.

\section{Reference}

[1] D.W. Donigian, J.N. Ishley, K.J. Wise: TAPPI J. 80 (5) (1997), p.145.

[2] T.P. Glatter, D.W. Bousfield: TAPPI J. 80 (7) (1997), p.125.

[3] D. M. Desjumaux, D.W. Bousfield: Progress in Organic Coatings. 38(2) (2000), p.89.

[4] M.T. Prykäri, E. Alarousu, H. Koivula, M. Myllys, A. Lähteelä, M. Toivakka, J. Timonen, R. Myllyl”a and K.-E. Peiponen: Colloids Surf., A299 (2007)p.101.

[5] P. Heikkil€a and N. Milosavljevic: Drying Technology 20 (1) (2002), p.211.

[6] S. Rousu, P.A.C. Gane, D. Speilmann: Nordic Pulp Paper Res. J. 15 (5) (2001), p.527.

[7] J.S. Preston, N.J. Elton, A. Legrix, C. Nutbeem: Proceeding of TAPPI Advanced Coating Fundamentals Symposium, San Diego, May 2001.

[8] G. Udupa, M. Singaperumal, R.S. Sirohi, M.P. Kothiyal, Meas. Sci. Technol. 11 (2000), p.315.

[9]C. M. Tåg, M. Juuti, K. E. Peiponen, J.B. Rosenholm, Colloids Surf. A 317 (2008), p.658. 